\title{
The Process Management of Graduation Design Based on Its Characteristics
}

\author{
Bin Sun* \\ Industrial Center, Nanjing Institute of Technology, 211167 Jiangning Nanjing, China
}

\begin{abstract}
This paper sums up six features and three functions as the characteristics of graduation design, which is the last link of undergraduate education. And through the analysis of each link in the graduation design process, this paper gives an improvement method for the graduation design based on these characteristics. Finally, an application example of this improvement in our university is given.
\end{abstract}

\section{Overview}

In order to maximize the teaching effect of graduation design for undergraduates, we should have a comprehensive understanding of the characteristics of graduation design, which include its features and functions. $[1,2]$ In the process of teaching practice, some corresponding countermeasures should be designed in view of these characteristics, to ensure the quality of graduation design. This paper summarizes the characteristics of graduation design in detail based on the practice of graduation design guidance, include 6 features and 3 functions, and makes a countermeasure design for each stage of graduation design process based on these characteristics and functions. Practice proves that the process management method proposed in this paper can effectively solve the problems that may appear in the graduation project and improve the quality of the graduation project.

\section{Research status}

The research on the characteristics of graduation design has a long history. For example: In Literature 3, in view of the innovative mode of graduation design (Thesis) for Food Science and Engineering major in application-oriented universities, Li Wen constructed the process control mode of graduation design for this major in Application-oriented Universities based on OBE (Outcomes-based Education). In Literature 4, Qin Xun took the graduation design of application-oriented universities as the research objects, and discussed the classification, purpose, existing problems and principles of graduation design in details.

\section{Characteristics of Graduation Design}

\footnotetext{
* Corresponding author:2875700829@qq.com
} 
In this paper, we refined there is 6 features and 3 functions in the characteristics of graduation design, which should be considered in graduation design guidance.

\subsection{The features of graduation design}

The features of graduation design can be listed in Fig.1:

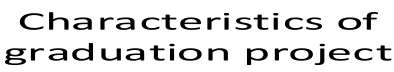

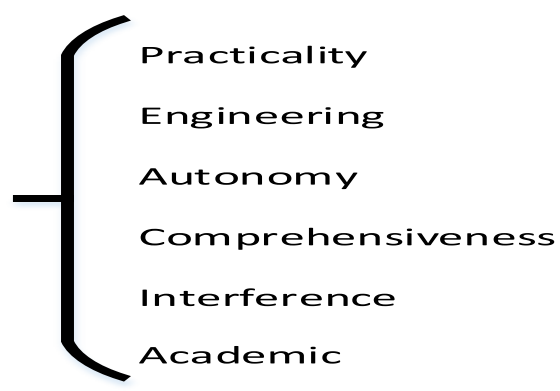

Fig.1. The Features of Graduation Design

First, it is practical. It's an important practice process in the undergraduate stage. This is mainly reflected in that it is a practical activity with the highest level, the longest time and the closest to practical application in the process of undergraduate teaching. Second, it has engineering nature. It's the only complete engineering practice in the undergraduate stage. Based on this nature, undergraduates need the guidance and help of instructors. Third, it has autonomy nature. It's a teaching activity driven by students themselves in the undergraduate stage. In the process of undergraduate graduation design, the instructor can play three roles: leader, educator and helper. However, the main body of the graduation project is the students. Generally, the instructor should not be directly involved in the process of the graduation project, but took the students as the main body to complete the graduation project. Fourth, it is comprehensive. The graduation design in science and engineering universities is generally comprehensive design or research, which investigates the comprehensive quality of students and the ability to solve unknown problems. Fifthly, it has interference. Because the graduation project is completed before graduation, it overlaps with the graduation job, so it needs reasonable time arrangement. Sixth, it is academic. The practical operation of graduation design needs theoretical analysis and academic content. Therefore, it is an important ability promotion for undergraduates.

\subsection{The function of Graduation Design}

Graduation design has 3 functions as shown in the following Fig.2:

Test function

The function of graduation project

Learning function

Innovation function

Fig.2. The functions of Graduation Design 
First, it has the function of inspection. It is a complete examination of undergraduate knowledge. Second, it has the function of learning. It is not the end of undergraduate education, but an important part of undergraduate education. Graduation design should not only have the function of inspection, but also make undergraduates have deeper knowledge in a certain field on the basis of undergraduate education. Third, it plays an innovative role. General undergraduate graduation design requires certain innovative content. [3, 4] Undergraduate students are required to integrate their innovative thinking into their graduation design.

The characteristics of graduation design run through the whole process of graduation design. So, understanding these characteristics has a certain guiding function in improving the process of our graduation design. [5]

\section{Improvement of Graduation Design Based on Characteristics and Functions}

For the process of graduation design, $[6,7]$ it mainly includes the following stages: Topic selection stage, Opening stage, Capstone presentation, Research (design) stage 1, Mid-term inspection stage, Research (design) stage 2, Defense stage and Post-defense stage. Generally, the distribution of these stages is shown in Fig.3 as below.

\begin{tabular}{|c|c|c|c|c|c|c|c|c|c|c|c|}
\hline Toncselettion & Operingstage & Canstone & & | (Design) & & Mildeterm & & (Design) & & Defensestage & Postdetense \\
\hline WeekO & Week1 & Week2 & Week2 & "'m!" & Week7 & Weel8 & Weekg & "'m!" & Week14 & Week 15 & Week16 \\
\hline
\end{tabular}

Fig.3. The process of graduation design

On the basis of the above characteristics, we can make some improvements to the graduation design according to the characteristics of the graduation design. And these improvements can make the graduation design more effective.

\subsection{Topic selection stage}

At the stage of topic selection, the instructor usually formulates the subject of graduation design, and gives the specific requirements of the subject. The quality of the title plays a decisive function in the final result of the graduation project. [8] Therefore, teachers should fully consider the impact of the characteristics of the above-mentioned graduation project. Generally speaking, when a teacher has worked out the topic, he should have a basic framework for the complete process of graduation design. In the course of project design, the features of graduation design should be taken into account, such as:

Learning requirement that graduation design should based on existing knowledge and new knowledge should been expanded. Interfering requirement that graduation design should take other interfering factors into account, that is what students may encountered in the process of graduation design. Therefore, the task of graduation design cannot be designed too full, and students need to be allowed a margin. Generally speaking, in the stage of the project design process, we will consider the following items to understand the specific situation of the project 
Table 1. Considerations at the design stage of the project

\begin{tabular}{|c|c|}
\hline $\begin{array}{c}\text { Contents to be considered in } \\
\text { project formulation }\end{array}$ & Detailed description \\
\hline $\begin{array}{c}\text { Study content and difficulty } \\
\text { coefficient }\end{array}$ & $\begin{array}{c}\text { Considering the new learning content and difficulty of this } \\
\text { subject, it reflects the learning nature }\end{array}$ \\
\hline $\begin{array}{c}\text { Task quantity and difficulty } \\
\text { coefficient }\end{array}$ & $\begin{array}{c}\text { Considering the content and difficulty of the task, it reflects the } \\
\text { comprehensiveness }\end{array}$ \\
\hline $\begin{array}{c}\text { Practice content and difficulty } \\
\text { coefficient }\end{array}$ & $\begin{array}{c}\text { Considering the practical content and difficulty of this subject, it } \\
\text { reflects the practicality }\end{array}$ \\
\hline $\begin{array}{c}\text { Engineering system and its } \\
\text { difficulty coefficient }\end{array}$ & $\begin{array}{c}\text { Considering the engineering system module design and its } \\
\text { difficulty, it reflects the engineering }\end{array}$ \\
\hline $\begin{array}{c}\text { Interference consideration factor } \\
\text { is reflected }\end{array}$ \\
\hline $\begin{array}{c}\text { Academic content and its } \\
\text { difficulty coefficient }\end{array}$ & $\begin{array}{c}\text { Considering the interference and its coefficience } \\
\text { this subject, it reflects the academic nature }\end{array}$ \\
\hline
\end{tabular}

Based on the above considerations, we can give the comprehensive difficulty coefficient of graduation design. And then we can give the corresponding opinions for student's graduation design topics.

\subsection{Opening and opening defense stage}

The opening and opening defense stage is the preparation stage of graduation project. In this stage, students complete literature collection, overall scheme design, schedule and other work under the guidance of the instructor. [9] The completion of the opening stage determines the depth and level of graduation design. Considering the interference of graduation design, in this stage, the instructor should have more guidance to students, such as: designate student's literature, programs and progress, so as to enable students to enter the research stage smoothly. We suggest that it is best to give students full autonomy. And then we can screen their collected literature, and modify the design scheme, and give predictive reminders to the student's progress arrangement, taking into account the interference factors. So that students can change from pure learning stage to engineering practice stage of graduation design smoothly.

\subsection{Research (Design) stage}

Research (design) stage is the main part of graduation design, the main body of this stage is students, and the instructor should pay attention to whether his progress conforms to the schedule. $[10,11]$ In our practice process, considering the engineering nature of graduation design, the instructor will guide the students to refine their graduation design topics at the opening stage, that is, systematically treat graduation design as a small system, decompose it into sub-modules, take these sub-modules as sub-topics, and schedule it in 2-3 weeks. Completing the sub project tasks of each stage one by one can effectively avoid the problems that students have nowhere to start. And this way can effectively avoid the problem of proxy of the project - because students need to feedback part of the design every period of practice, so that students can always be in the process of graduation design. And the instructor also can grasp the student's completion situation in real time and solve the problems in time. 


\subsection{Mid-term inspection stage}

The mid-term inspection stage is a supervisory measure for the student's research (design) stage, which can discover and solve problems in time. Therefore, in the process of practice, we will concretize the mid-term inspection and further quantify the student's graduation design. The contents of the inspection include:

Table 2.Inspection items and contents

\begin{tabular}{|c|c|}
\hline Inspection items & Inspection contents \\
\hline Progress completion & Check according to about 50\% of the planned progress as the benchmark \\
\hline Learning content & Check according to the learning content of graduation project \\
\hline Practice content & Check according to the practice content of graduation project \\
\hline System function & Check according to the completion of graduation project system function \\
\hline Academic situation & Check according to the academic situation of graduation project thesis \\
\hline Interference & Check the absence of work and other situations during graduation design \\
\hline
\end{tabular}

In the process of inspecting these projects, we can find out the problems existing in the process of completing graduation design in time and solve them according to the characteristics of graduation design. This solution can make the mid-term inspection more specific and enforceable.

\subsection{Defence stage}

The defence stage is the stage in which students summarize the results of graduation design, complete the writing of thesis and make the final defence of graduation design. This stage should not only pay attention to the standardization of the thesis, but also pay attention to the logic of the content of the thesis. In addition, the defense stage is not only the examination on paper, but also the process of defense, which is the investigation of student's comprehensive quality. Therefore, the results of graduation design defense generally include three aspects: the evaluation score of the instructor, the evaluation score of the teacher and the on-site score of the defense expert. The instructor's review score mainly considers the student's normal performance, the completion of the practice process and the realization of the system, while the review teacher's mainly considers the standardization of students' papers, the presentation of student's achievements and the logic of the papers. On the other hand, the on-the-spot scoring of the defense experts can comprehensively understand the students' mastery of the graduation project. Therefore, the defense can reflect the student's efforts and abilities more comprehensively.

At this stage, graduation design is nearly completed. In the process of reviewing and evaluating, teachers generally make corresponding evaluations on student's graduation design according to the characteristics of graduation design, such as whether the graduation design is innovative or not, and how the project and practice of graduation design are completed, all of which should be evaluated objectively.

\subsection{Post-defense stage}

As the end of graduation design, the post-defense stage is the stage of collecting and collating the results of graduation design. The main task of this stage is to modify, collate 
and submit the final submission of graduation design and graduation design thesis. After the final revision and improvement of the graduation design data, the instructor should conduct the final audit. At this stage, students need to summarize the results of the whole process of graduation design, and the instructor generally needs to make a summary of the subject of graduation design guidance. Generally speaking, we will give a score on the relevant issues of this graduation project and give suggestions for further improvement. On the one hand, these opinions are the summary of this graduation project work, on the other hand, they can also make directional opinions on further research and work.

\section{Analysis of actual effect}

Fig.4 is a "Weekly Progress Report" (" WPR" for short),which we can know what have been done in this week by this student. As shown in Fig.4, it is a "WPR" of the first week which filled in by the student who is in the process of completing the graduation project. In this report, we can know that in this week, the student is familiar with the task content of his graduation project. He has also completed the translation of English paper, and has made minor modifications for this translation in this week. In addition, he also completed the opening report in this week. And in this page, we can also give some guidance about what they should do in next week according what he has done in this week.

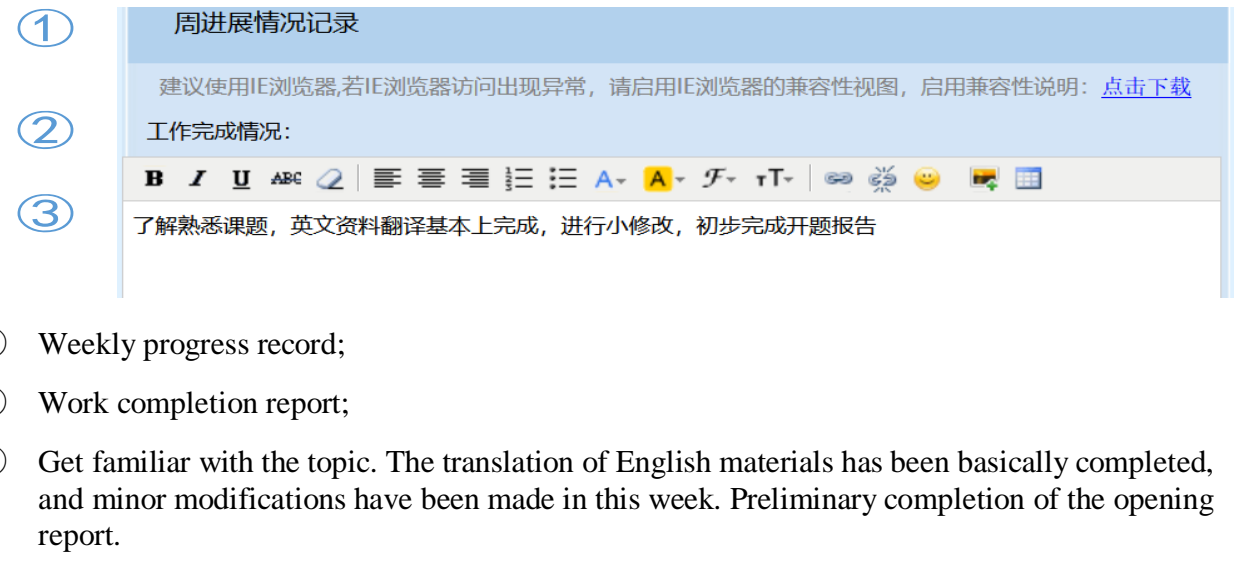

Fig.4 Weekly progress record
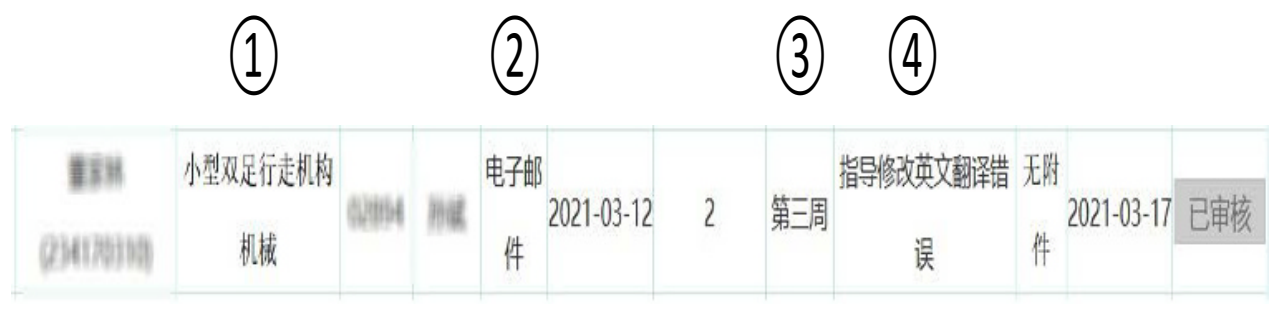

(1) Mechanical design of small bipedal walking mechanism;

(2) E-Mail;

(3) Week 3;

(4) Guide the correction of errors in English translation.

Fig.5 Guidance Log 
The Guidance Log records the weekly guidance, as shown in Fig.5. It is the guidance $\log$ of the third week of a student's graduation project. In Fig.5, we can see that the instructor further guided the correction of errors which in English translation paper in this week. Through this guidance log, it is convenient to track the guidance of graduation project, and find the problems in the process of guidance in time.

Through the above process management method, we can effectively ensure the quality of graduation design, timely adjust the work progress of students in the graduation design process, ensure the graduation design to be completed on time, and cultivate the planning ability of students when they are engaged in engineering and other practical work.

\section{Summary}

Graduation design is the last link of undergraduate teaching, which can reflect the comprehensive practical ability of students, and the graduation design work can also reflect the ability of talent cultivation in schools. In order to improve the teaching level of graduation design, we need to recognize the characteristics of graduation design, and improve our graduation design work according to these characteristics. As a result ,We will make the graduation project not only to be a teaching process, but also to be an important and effective practical activity for students to study how to work.

\section{References}

1. Y.Tao. Implementation and Enlightenment of graduation project of industrial engineering major in University of Michigan. Chinese University Teaching.11, 94-96, 2018.

2. J.B.Zhu, Q.S.Li,Y.Z.Fu, The role of engineering graduation design teachers and their influence on learning input and learning effectiveness, Research in Higher Education of Engineering.2,81-87,2021.

3. W.Li, T.Wang. Research on the innovation mode of graduation design of food science and engineering major in Applied Undergraduate Colleges Based on OBE. Journal of Southwest China Normal University(Natural Science Edition). 2,176-180, 2021.

4. X Qing. Innovative research on graduation design of application oriented Universities. Anhui University, Hefei, 2017.

5. L.Zhang, L.Zhang, F.Y.Liu, Y.Xu. Research on improving the quality of undergraduate graduation design (Thesis) of Electronic Science and technology. Research and Exploration in Laboratory.1:253-255+270.2020.

6. Q.Shen, Y.Zhang, Q.T.Gu. Quality control scheme design for graduation project of engineering major in application-oriented Undergraduate, Experimental Technology and Management,12:167-170, 2010.

7. F Yang. Research on the innovation of undergraduate graduation project teaching mode. Computer education,7: 74-77. 2010.

8. H.M.Li, W.Lu,X.D.Chen, W.W.Xing. Research and Practice on quality assurance system of graduation practice and design process management, Research in Higher Education of Engineering.6:167-171, 2012.

9. B.J.Wang, T.H.Wu, Y.G.Duan, Y.Q.Wang. Experimental teaching quality evaluation system based on Engineering Education Certification. Research and Exploration in Laboratory,5: 149-152+181, 2020. 
10. G.F.Li, P.Li, F.Z.Qing. The graduation project of computer major integrated with CDIO concept,Computer Education,8: 22-25+26. 2014

11. M Sun, W.B.Liu, Y.F.Wang. Research on the teaching mode of urban planning graduation design in Colleges and Universities based on CDIO theory, Forest Engineering,5: 113-117, 2012. 